\title{
Live in relationships: How India sees it compared to the rest of the world
}

\author{
Srijith $^{1^{*}}$, Anu $^{2}$, Santhosh CS $^{3}$ \\ ${ }^{1}$ Assistant Professor, ${ }^{2}$ Postgraduate Student, ${ }^{3}$ Professor and HOD, ${ }^{1,3}$ Dept. of Forensic Medicine, ${ }^{2}$ Dept. of Prosthodontics, ${ }^{1}$ Karpagam \\ Faculty of Medical Sciences and Research, Tamil Nadu, ${ }^{2}$ Government Dental College, Bangalore, Karnataka, ${ }^{3}$ J.J.M Medical College, \\ Davanagere, Karnataka, India
}

*Corresponding Author: Srijith

Email: srijithfun@gmail.com

\begin{abstract}
Live-in relationship is a living arrangement in which an unmarried couple lives together in a long term relationship that resembles a marriage. Of late, live-in relationships have emerged as a substitute for marriages. The number of people opting to live-in relationships has considerably increased in India. This article explores the response of the Indian society and Indian judiciary to live-in relationships comparing it to the rest of the world. In a country where parents sometimes even murder their children for marrying out of caste, many brave couples do live together without getting married. They face social disgrace and legal hurdles. Families cringe at the idea of live-in relationships because it hints at sex for pleasure instead of for procreation, which marriage implies. The countries in the West never consider marriage as a religious sacrament and do not show keen interest on fulfilling obligations towards the family and society. To conclude, things have definitely improved with Court rulings which have recognized these relationships and have made changes in provisions to protect a woman from undue harassment as these relations guarantee very little in terms of security.
\end{abstract}

Keywords: India, Live-in relationships, Marriage, Society, World.

\section{Introduction}

Marriage is a sacred institution, which has been in existence for centuries. It is the formal and holy union of a man and a woman for life, especially in a country like India, where marriage is considered not to be a contract but it is a sanskar or sacrament. ${ }^{1}$ With changing times the dimensions of commitment have changed and as a result people are exploring for alternatives to marriage. One such alternative is in the form of couples landing in live-in relationships. Live-in relationships are a walk in walk out relationship. There are no strings attached to these relationships as the relationship is free from any legal bond between the parties. $^{2}$ The number of people opting to live-in relationships has notably increased. The moral and ethical angle to the concept of live-in relationship is a subjective one, especially in a country like India. On one hand, a section of society is of the view that it will dilute the sacred institution of marriage as it encourages premarital sexual relationships; in fact, they consider it to be a sin. On the other hand, the liberal minds of the society consider it as a progressive and forward looking concept which allows the younger generation to check their compatibility with their partner before entering a permanent commitment through a valid legal marriage. ${ }^{3}$

The research article aims to know the reasons why couples choose live-in relationships as an alternative to marriage and the adverse outcomes if any that arises from these relationships. The study also aims to analyse the response of the Indian judiciary to live-in relationships and to know the status of live-in relationships in other countries around the globe.

\section{Main Text}

Why do Couples Choose live-in Relationships?

Before getting married legally, couples prefer to know the likes and dislikes of the partner. They have no social or financial obligations and can easily separate from each other without any guilt in case they feel their frequencies do not match. By being in such a relationship, a sense of maturity is developed amongst the partners who help them in being with each other later in life. ${ }^{4}$

\section{What are the Adverse Outcomes Arising from live-in Relationships?}

Live-in relationships are not easily accepted by society, especially by the orthodox Indian society. Lack of commitment in a relationship may lead to couples losing interest in each other. Such relationships allow men to desert the woman after having exploited her sexually with a false promise of marriage.

Any unwanted pregnancy or childbirth resulting from a live-in relationship results in an unknown status regarding the legitimacy of the child, and thereby problems with regard to the inheritance of property.

On the other hand, failure or separation of a couple in a live-in relationship can result in the woman maliciously slapping charges of rape against the man. ${ }^{4}$

What is the response of the Indian judiciary and the Indian society to live-in relationships?

According to the Hindu religion, it is very necessary for a man and a woman to marry in order to achieve the four ideals of life-Dharma, Artha, Kama and Moksha. ${ }^{5}$

Tracing the roots in ancient India, marriage was considered necessary for the complete fulfilment of the purpose of life of men and women, without which it was believed that they could not achieve Moksha. ${ }^{6}$ 
In Indian society, a woman is traditionally seen as a "goddess". ${ }^{7}$ The traditional concept of a Hindu marriage is a religious sacrament referring to a lifelong commitment, the true purpose being a complete companionship in fighting the battle of life together. ${ }^{6}$

Parents continue to live in denial at the idea of a live-in relationship because for them, in hints at sex for pleasure instead of for procreation, which marriage implies.

Article 21 of the Indian constitution grants the right to life and liberty as a fundamental right, ${ }^{8}$ but it does not include socially accepted relationship such as live in relation. Where a man and a woman live together for a long spell of time as husband and wife then there would be a presumption of marriage as per S.114 of Indian Evidence Act, $1872 .{ }^{9}$

As early as 1927,in a case A.Dinohamy v/s WL Blahemy, ${ }^{10}$ the Council laid down the general principle "Where a man and woman are proved to have lived together as a man and wife, the law will presume, unless the contrary be clearly proved, that they were living together in consequence of a valid marriage and not in a state of concubinage". The same stand was resorted to in the case of Mohabhat Ali v/s Md.Ibrahim Khan ${ }^{11}$ two years later when the Council stated that when a man and woman cohabitated continuously for a number of years, the law presumes that they are a married couple and not in a state of concubinage. However in none of the above cases has the judiciary declared the number of years a couple should live together as husband and wife to get the benefit of these judgements and enjoy the rights flowing from it.

In 1952, in a case between Gokul chand v/s Parvin Kumari, ${ }^{12}$ the Apex Court reiterated the 1929 principle, but added a caveat. It said that though the presumptions of a valid marriage between live-in couples could be drawn from their long cohabitation; it was no guarantee to earn them legitimacy, if the evidence regarding living together was rebuttable.

In a case, Badri Prasad v/s Dy.Director of Consolidation, ${ }^{13} 1978$ where a man and woman lived together for around 50 years, the Apex Court presumed that they were a married couple.

In 2001, Payal Sharma v/s Superintendent, Nari Niketan, Agra, CM Hab Corp,${ }^{14}$ the Bench observed that "In our opinion, a man and a woman even without getting married, can live together if they wish so. This may be regarded as immortal by society, but is not illegal".

In Patel and others case, ${ }^{15}$ the Apex Court observed that the two adults are not criminal offenders who are bound in a live-in relationship without a formal marriage. No legislation has ever been enacted by Indian parliament which denounces any live-in relationship as illegal. The above judgement was made applicable to Tulsa v/s Durghatiya ${ }^{16}$ by the Apex Court and re-recognised the rule that there would be a presumption of marriage under section 114 of Indian Evidence Act when there has been long cohabitation.

It was only after 2010 that various issues were discussed and clarified by the Supreme Court and High
Court by delivering various guidelines in numerous judgements on the validity of live-in relationships.

In 2010, a special bench of Apex Court of India consisting of KG Balakrishnan, Deepak Verma, BS Chauhan in Khusbhoo v/s Kanniammal \& Anr case ${ }^{17}$ wherein a question was posed, "If two people, man and woman, want to live together, who can oppose them? What is the offence they commit here? This happens because of cultural exchange between people". The Apex Court held that live- in relationship is permissible. The Court also held that living together is a part of the right to life under Article 21 of the Indian Constitution ${ }^{8,18}$ and it is not a criminal offence. The three judges further stated that living together is not an offence, and it cannot be an offence. ${ }^{19}$ In this context, the court commented that there exists no law in the country which prohibits premarital sex. This comment was passed by the Apex Court in answer to the comments made by the prosecution that the actress Khusboo endorsed premarital sex which affects the moral fabric of the society. ${ }^{18}$

Another case heard in 2010 in the Delhi High Court, Alok Kumar v/s State $^{20}$ termed live-in relationship as a contract of living together which is renewed every day by the parties and can be terminated by either of the parties without the consent of the other party. Thus couples opting for live-in relationship cannot later complain of infidelity or immorality.

In 2011, a special bench of the Apex Court consisting of GS Singhvi, Asok Kumar Ganguly in Revanasiddappa \& Anr v/s Mallikarjun \& $\mathrm{Ors}^{21}$ remarked that irrespective of the relationship between parents, the birth of a child out of such relationship has to be viewed independently of the relationship of the parents. The bench further opined that it is as plain and clear as sunshine that a child born out of such relationship is innocent and is entitled to all the rights and privileges available to children born out of a valid marriage.

Domestic violence is a complex pattern of behaviour that may include in addition to physical acts of violence, sexual abuse and emotional abuse. Domestic violence happens to everyone. All races, all religions, all income and education levels ${ }^{22}$ In a case concerning domestic violence on a woman in a live-in relationship, the Apex Court judges, GS Singhvi and Asok Kumar Ganguly ${ }^{23}$ declared that woman in live-in relationship are equally entitled to all the reliefs which are available to a legally wedded wife. A woman's response to abuse is often limited by the options available to her. Women consistently cite similar reasons for remaining in abusive relationships: fear of retribution, lack of other means of economic support, concern for children, emotional dependence, lack of support from family and friends and an abiding hope that "he will change".

In a case Velusamy v/s D.Patchaiammal, ${ }^{24}$ D.Velusamy was aggrieved over a Madras High Court judgement upholding a Coimbatore trial court order, awarding maintenance of rupees 500 to respondent D.Patchaiammal, declaring her his wife, though his first marriage with Lakshmi was not dissolved. The Bench set aside the impugned judgement of the High Court and the Family 
Court Judge, Coimbatore and remanded the matter to the Family Court Judge to decide the matter afresh in accordance with the law and in the light of its observations. ${ }^{25}$ While giving a judgement in this case, the Apex Court commented in the course of its judgement that the Indian parliament while establishing the two distinct categories, "relationship of marriage" and "relationship in the nature of marriage" intended that the enactment should protect and benefit the woman in both these relationships. Therefore the Apex Court held that "relationship in the nature of marriage" is akin to common law marriage. Common law marriages require that although not being formally married:

1. The couple must hold themselves out to society as being akin to spouses,

2. They must be of legal age to marry,

3. They must be otherwise qualified to enter into a legal marriage, including being unmarried,

4. They must have voluntarily cohabited and held themselves out to the world as being akin to spouses for a significant period of time.

The judgement further classified the essentials of a common law marriage and stated that not all live-in relationships will amount to a "relationship in the nature of marriage". 24,26

In 2013, a two-judge bench of Apex Court consisting of KS Radhakrishnan and Pinaki Chandra Ghose, in Indra Sarma v/s VKV Sarma ${ }^{27}$ felt that denial of any protection would amount to a great injustice to victims of illegal relationship who are poor, illiterate and also to their children who are born out of such relationship and has no income of her own. With an intention to help such victims, the Apex Court, purely out of humanitarian consideration, suggested a legislation which would prove to be an effective remedy to a societal wrong caused by such illegal relationships. A few suggestions from the Apex Court include:

1. Duration of the relationship-a reasonable period of time to maintain and continue a relationship which may vary from case to case (again the lacunae remains unfilled).

2. The pooling of resources and financial arrangementssupporting each other, sharing bank accounts, acquiring immovable properties in joint names, long term investment in the business.

3. Domestic arrangements-Entrusting the responsibility, especially on the woman to run the home, do household activities like cleaning, cooking, maintaining or up keeping the house, etc is an indication of a relationship in the nature of marriage.

4. Sexual relationship-Marriage like relationship refers to a sexual relationship, not just for pleasure, but for an emotional and intimate relationship, for procreation of children, so as to give emotional support, companionship and also marital affection, caring, etc.

5. Socialization in public-Holding out to the public and socializing with friends, relations and others, as if they are husband and wife is a strong circumstance to hold the relationship is in the nature of marriage.
The Malimath Committee ${ }^{28}$ too made several recommendations that the definition of the word wife in Section 125 Criminal Procedure Code should be amended so as to include a woman who was living with the man as his wife for a remarkably long period, during the subsistence of the first marriage. ${ }^{29}$ This even opens the door for alimony in live-in relationships. ${ }^{30}$ In a bold step, the Maharashtra cabinet approved a proposal suggesting a woman involved in such a relationship for a 'reasonable period' should get status of wife. ${ }^{31}$

In 2014, a bench of Justices BS Chauhan and Chelameswar said that children born out of prolonged livein relationships could not be termed illegitimate. ${ }^{32}$

In one of the recent judgements in 2015, a bench of justices MY Eqbal and Amitava Roy said continuous cohabitation of a couple would raise the presumption of a valid marriage and it would be for the opposite party to prove that they were not legally married. ${ }^{33}$

Live-in relationships will certainly not endanger the institution of marriage which the majority will continue to uphold. However, the small minority who wish to do it their way ought to be allowed to do so. It is a question of the individual right of choice, integral to personal freedom and the importance of tolerance without resorting to stereotyping individual behaviour. Moral policing is not the domain of the court or society. As society moves more towards contract and becomes less stratified, an individual's choice will become more and more pronounced. ${ }^{26} \mathrm{Good}$ relationships can boost confidence and keep individuals motivated to achieve greater personal goals. ${ }^{[34]}$ Even the internet has extended its matchmaking services to include live-in partners. Recently a few non-government organisations too organised a first of its kind event to help senior citizens find companions. ${ }^{35}$

The problems seen these days arising from live-in relationships is the inability of couples to find a suitable house to stay for rent. Considering the mentality of the Indian society, no house owner would allow couples in a live-in relationship to be his tenants. Similarly, on booking hotels, to avoid unpleasant arguments at a later stage, hotels clearly mention in their website that they entertain married couple only. ${ }^{35}$

Recently an elderly couple in Kerala reluctantly married after 40 years of living together. Having taken the ideological position that their relationship was not dependent on social sanction, they had to alter course when they felt that the legal rights of their family, including the grandchildren, were threatened. Additionally not everyone wants their children to face and be confused by people's questions about their parent's unconventional union. ${ }^{35}$

Over the years, there have been several Bollywood movies that have showcased the pros and cons of being involved in such a relationship, such as Salaam Namaste, Shuddh Desi Romance, Cocktail, Bachna E Haseeno, Fashion, Pyar ka punchnama and Befikre. ${ }^{36}$ At a trailer launch of film 'Half Girlfriend', an adaptation of Chetan Bhagat's novel by the same name, actress Shraddha Kapoor when questioned about the concept of live-in relationship to 
the Indian audience replied that with every passing generation there is a revolution in terms of one's ideologies and people should go ahead with whatever continues to make them feel happier. ${ }^{37}$

\section{What is the status of live-in Relationships across Countries around the Globe?}

The western ideology of marriage regards marriage as a personal matter concerned with love making, home making and living together. They never consider marriage as a religious sacrament and do not show keen interest in fulfilling obligations towards the family and society.

\section{USA}

A term 'palimony' was introduced which refers to providing maintenance to a woman who lived for a substantial period of time with a man without marrying him and is then deserted by him. The first decision on palimony was taken in a case Taylor v/s Fields ${ }^{38,39}$ and Marvin v/s Marvin ${ }^{40}$ involving the famous actor Lee Marvin with whom a lady Michelle lived for many years without marrying him and was then deserted by him and she claimed palimony.

Although there is no statutory basis for the grant of palimony in the USA, the courts there have granted it on a contractual basis. Some Courts in USA have held that there must be a written or oral agreement between the man and woman that if they separate, the man will give palimony to the woman, while the Courts have held that if a man and woman have lived together for a substantially long period without getting married, there would be deemed to be an implied or constructive contract that palimony will be given on their separation. ${ }^{41,42}$

A new study by Arielle Kuperberg that appeared in the US-based Journal of Marriage and Family this April, has found something interesting. These days, most people who move in together, do so to test the longevity of a relationship. In other words, they view live in relationship as a step towards marriage, rather than a "rebellion" against it. The study which analysed over 7000 people in the US states that cohabitation has grown by $900 \%$ in the past five decades. The study also found out those two-thirds of the couples who got married in 2012, had lived together before marrying. This phenomenon, in turn, has reduced the divorce rate in the US. ${ }^{43}$

\section{UK}

Live-in couples do not enjoy legal benefits and status which are granted to married couples. People in such a relationship are free from all bindings. Partners do not have inheritance rights over each other's property and there is no provision for Bereavement Allowance to widowed spouses. However the law seeks to protect the rights of a child born under such a relationship. Both the parents have the onus of bringing up their children. ${ }^{44,45}$

\section{Canada}

Canada recognises live-in relationships as common law marriage. It grants common-law partners the same fundamental rights as married couples after two years of cohabitation. ${ }^{46,47}$

\section{France}

The French parliament passed legislation in November 1999 allowing couples to enter into a union by signing before a court clerk. It is a contractual form which binds "two adults of different sexes or of the same sex, in order to organise their joint life". 48,49

\section{China}

In China, a couple can sign a contract to live-in relationship. The rights of a child are secured as a child born outside the wedlock has the same benefits as enjoyed by the child born under a marriage. ${ }^{50}$

\section{Declarations}

Ethics approval and consent to participate: Waived off as per the Institutional Ethics Committee,KFMSR

Consent for publication: Not applicable

Availability of data and material: Not applicable

Competing interests: The authors declare that they have no competing interests

Funding agencies: Not applicable

Acknowledgements: Not applicable

\section{Conclusion}

Live in relationships are like mutual funds, you always invest at your own risk. Live in relationships have always been in the ambit of debates and discussions. There has been a longstanding controversy whether a relationship between a man and a woman living together without marriage can be recognised by the law. With changing social hypothesis entering society, in most places, it is legal for unmarried people to live together. Now even in a country like India bounded by innumerable cultural ethos and rites, the law finds legally nothing wrong in live in relationships. Owing to surmounting number of such cases, the Supreme Court is simply acknowledging the social reality. Moreover, law does not prescribe how we should live; it is ethics and social norms which explain the essence of living.

\section{Conflict of Interest: None.}

\section{References}

1. Sonali Abhang.Judicial approach to live in relationship in India-its impact on other related statutes. ISOR J Hum Soc Sci 19(12);2014:28-38

2. Deswal V.Decoding the dynamics of live in relationships.Lifestyle Blogs[Internet].The Times of India[cited 2019 March 4]. Available from: https://timesofindia.indiatimes.com/blogs/legallyspeaking/decoding-the-dynamics-of-live-in-relationships/.

3. Mohit Chhibber,Aditya Singh.Live in relationships:An ethical and a moral dilemma? Int J Appl Res 2015;1(8):74-7

4. Vishaka G.Live in relationships and emerging legal issues in India. iPleaders Blog[Internet].[cited 2015 January 
30].Available from:https://blog.ipleaders.in/live-inrelationships-and-emerging-legal-issues-in-india/vishaka.

5. Eknath Easwaran.Attainment of Salvation.Bhagavad Gita. Nilgiri press. $2^{\text {nd }}$ ed;2007:76

6. Duncan Mitchell.A dictionary of sociology. Aldine Publishing Company;1968:132

7. Bride burning.V Kumar,S.Kanth.The Lancet;Dec2004:18

8. Fundamental Rights in India. Wikipedia contributors.Wikipedia, The Free Encyclopedia[retrieved 2018 January 27].Available from:

https://en.wikipedia.org/w/index.php?title=Fundamental_rig hts_in_India\&oldid=902113752.

9. Indian Evidence Act.Criminal Manual.Universal law publishing;2018:656

10. SC ruling on live-in couples may give women right to inherit.The Times of India.e-paper[cited 2008 January 21].Available from: https://timesofindia.indiatimes.com/india/SC-ruling-on-livein-couples-may-give-women-right-toinherit/articleshow/2716255.cms.

11. Shaw.Mohabhat Ali Khan vs Md. Ibrahim Khan. Bombay High Court.Archived cases[cited 1929 March 7].Available from: https://indiankanoon.org/doc/242625/.

12. Ali SF.Gokul chand vs Parvin Kumari. Supreme Court of India. Archived cases [cited 1952 May 16].Available from:https://indiankanoon.org/doc/1388066/.

13. Krishnaiyer V.Badri Prasad vs Dy.Director of Consolidation.Supreme Court of India.Archived cases[cited 1978 August 1].Available from: https://indiankanoon.org/doc/215649/.

14. Payal Sharma vs Superintendent, Nari Niketan, Agra,CM Hab Corp. Allahabad High Court. Archived cases[cited 2001 May 17].Available from: https://www.lawskills.in/FreeRes/judgments/MANUUP028 82001.htm.

15. Venkataramiah E. All India Reporter Karamchari vs All India Reporter Limited And Ors. Supreme Court of India. Archived cases[cited 1988 May 2]. Available from: https://indiankanoon.org/doc/1559915/.

16. 16)Shirin ZH,Pooja DP.Right of maintenance to women in live in relationships. Legally India Blog[Internet].[cited 2015 October 29].Available

from:https://www.legallyindia.com/blogs/right-ofmaintenance-to-women-in-live-in-relationships.

17. 17)Chauhan BS. Khushboo S vs Kanniammal \& Anr.Supreme Court of India. Archived cases[cited 2010 April 28].Available from: https://indiankanoon.org/doc/1327342/.

18. Krishnadas Rajagopal. Living together a part of right to life,not an offence:SC. The Indian Express.e-paper[cited 2010 March 24].Available

from:http://archive.indianexpress.com/news/living-togethera-part-of-right-to-life-not-an-offence-sc/594925/.

19. Living together is not an offence, it cannot be an offence.The Times of India.e-paper[cited 2010 March 23].Available from:

https://timesofindia.indiatimes.com/india/Live-inrelationship-pre-marital-sex-not-an-offenceSC/articleshow/5716545.cms.

20. 20)Dhingra SN. Alok Kumar vs State \& Anr.Delhi High Court. Archived cases [cited 2010 August 9].Available from: https://indiankanoon.org/doc/79779528/.

21. Revanasiddappa vs Mallikarjun(2011).Human and Civil Rights.The Practical Lawyer. Archived cases[cited 2011 March 31].Available

from:http://www.supremecourtcases.com/index2.php?option =com_content\&itemid=99999999\&do_pdf=1\&id=23071.
22. May KT. 6 brave personal stories of domestic abuse. TED Blog[Internet]. [posted 2013 January 25].Available from: https://blog.ted.com/5-brave-personal-stories-of-domesticabuse/.

23. Kalpana K.Women and Law:Critical Feminist Perspectives.ebook.2013.p26.Availablefrom:https://books.google.co.in/bo oks?id=W_WnAwAAQBAJ\&pg=PA26\&lpg=PA26\&dq=M ANU/SC/0807/2010\&source $=$ bl\&ots $=$ aCg YHz0e9C\&sig $=P$ KtUsIjNFgmnWxRI44Tn1irO9Rc\&hl=en\&sa=X\&ved=0ah UKEwjGq6CU6_rZAhVJQI8KHeXBAvoQ6AEIOjAC\#v=0 nepage \&q=MANU\%2FSC $\% 2 F 0807 \% 2 F 2010 \& \mathrm{f}=$ false.

24. D. Velusamy vs D. Patchaiammal(2010). Human and Civil Rights. The Practical Lawyer. Archived cases[cited 2010 October 21].Available

from:https://www.supremecourtcases.com/index2.php?optio n=com_content\&itemid=99999999\&do_pdf $=1 \& i d=19888$.

25. Not all live in affairs are relationship in the nature of marriage: SC. The Hindu.e-paper[cited 2010 October 22]. Available from:

http://www.thehindu.com/news/national/Supreme-Courtnot-all-live-in-affairs-are-lsquorelationship-in-the-nature-ofmarriage/article15786886/.

26. Sushila R.Legitimising live in relationships.A way of life. The Statesman. Web archive[cited 2013 December 22].Available from:

https://www.thestatesman.com/opinion/a-way-of-life30955.html

27. Gautam B. Indra Sarma vs VKV Sarma: The Supreme Court on Live-in relationships and Gay marriages. Indian Constitutional Law and Philosophy Blog[Internet].[cited 2013 November 30].Available

from:https://indconlawphil.wordpress.com/2013/11/30/indra -sarma-v-vkv-sarma-the-supreme-court-on-live-inrelationships-and-gay-marriage/.

28. Saxena A. Live in relationship and Indian judiciary. SCC Blog[Internet].[cited 2019 January 19].Available from:https://www.scconline.com/blog/post/2019/01/23/livein-relationship-and-indian-judiciary/.

29. Rebecca F.Live in relationships. iPleaders B $\log [$ Internet].[cited 2016 July 17].Available from:https://blog.ipleaders.in/live-in-relationships/.

30. Kumar SG.Push for alimony in live in relationships. The Telegraph.Online edition[cited 2006 December 12]. Available from: https://www.telegraphindia.com/india/pushfor-alimony-in-live-in-relationship/cid/746777.

31. Maharashtra to legalise live in relationships. The Times of India.e-paper[cited 2008 Oct 9].Available from: https://timesofindia.indiatimes.com/india/Maharashtra-tolegalise-live-in-relationships/articleshow/3575090.cms

32. Children born of live in relationships are legitimate:SC. The Times of India.e-paper[cited 2014 April 24]. Available from: https://timesofindia.indiatimes.com/india/Childrenborn-of-live-in-relationships-are-legitimate-Supreme-Courtsays/articleshow/34126867.cms.

33. Couple living together will be presumed married:SC. The Times of India.e-paper[cited 2015 April 13].Available from: https://timesofindia.indiatimes.com/india/Couple-livingtogether-will-be-presumed-married-Supreme-Courtrules/articleshow/46901198.cms.

34. Good relationships can boost your career.Lifestyle. The Indian Express.e-paper[cited 2017 September 25]. Available from: http://indianexpress.com/article/lifestyle/lifestyle/good-relationships-can-boost-your-career-4860640/.

35. Ankita A.The complete guide to live in relationships. Quartz.Web archive[cited 2014 November 28].Available from:https://qz.com/303608/the-complete-guide-to-live-inrelationships-in-india/. 
36. Richa G.12 movies that portrayed live in relationships differently. Farnaz Fever[cited 2017 Jan 11].Available from:http://www.farnazfever.com/article/12-moviesportrayed-live-relationships-differently.

37. Gayatri N.There are parents who understand their child is in a live in relationship: Shraddha. Deccan Chronicle.epaper[cited 2017 April 10].Available from: https://deccanchronicle.com/entertainment/bollywood/1004 17/there-are-parents-who-understand-their-child-is-in-alive-in-relationship-shraddha.html.

38. Taylor vs Fields.Justia US Law.Vol 178.Available from:https://law.justia.com/cases/california/court-ofappeal/3d/178/653.html.

39. Taylor vs Fields.Court of Appeals of Georgia.Findlaw.Available from:http://caselaw.findlaw.com/ga-court-ofappeals/1766212.html.

40. Marvin vs Marvin. Justia US Law.Vol 18.Available from:https://law.justia.com/cases/california/supremecourt/3d/18/660.html.

41. Cohabitation in the United States.Wikipedia contributors.Wikipedia,The Free Encyclopedia[retrieved 2018 Feb 28].Available from: https://en.wikipedia.org/w/index.php?title=Cohabitation_in_ the_United States\&oldid=884819946.

42. Lehmiller J.Sex and Psychology Blog[Internet].[cited 2013 Feb 6]Available from:https://www.lehmiller.com/blog/2013/2/6/livingtogether-before-marriage-still-illegal-in-4-us-states.html.

43. Sapna M.Live in relationships:A move towards marriage.Hindustan Times.e-paper[cited 2016 June 30]. Available from:https://www.hindustantimes.com/sex-andrelationships/live-in-relationships-a-move-towardsmarriage/story-G41aZGSaCO73eBY7Wo668I.html.

44. Olivia B.The top strain on relationships in UK revealed.Independent. Web archive[cited 2017 Mar 22].Available from: https://www.independent.co.uk/life- style/love-sex/biggest-strain-relationships-uk-relatea7642151.html.

gov.uk[Internet].Bereavement payment;c2017[cited 2017 April 10].Available from:https://www.gov.uk/bereavementpayment.

45. Common Law Marriage:Canada.Wikipedia contributors.Wikipedia,The Free Encyclopedia[retrieved $2018 \mathrm{Feb} 28]$.Available from: https://en.wikipedia.org/w/index.php?title=Commonlaw_marriage \&oldid=899973657

46. Justine M,Sinclair J.Common law couples as good as married in British Columbia[cited 2013 Mar 18].Available from:http://www.cbc.ca/news/canada/britishcolumbia/common-law-couples-as-good-as-married-in-b-c1.1413551.

47. Civil solidarity pact.Wikipedia contributors.Wikipedia,The Free Encyclopedia[retrieved 2018 Feb 28]Available from: https://en.wikipedia.org/w/index.php?title=Civil_solidarity_ pact\&oldid $=883987084$.

48. Louis DeSerres.Summaryof the French Parliamentary Com mission Report

49. On the Family And the Rights of Children[cited 2006 Jan 26]. Available from:http://familywatch.org/fwi/France_Report_Family_exe c_summary.pdf.

50. Charles C.What is different about dating in China?[cited 2018 Feb 28].Available from:https://www.thoughtco.com/dating-in-china-whatsdifferent-687348.

How to cite this article: Srijith, Anu, Santhosh CS, Live in relationships: How India sees it compared to the rest of the world. Indian $J$ Forensic Community Med 2019;6(2):49-54. 